\title{
Milliyet Cocuk and the Making of Childrens Literary Culture in Turkey in the 1970s
}

Deniz Arzuk Kocadere

The self-archived postprint version of this journal article is available at Linköping University Institutional Repository (DiVA):

http://urn.kb.se/resolve?urn=urn:nbn:se:liu:diva-158830

N.B.: When citing this work, cite the original publication.

Arzuk Kocadere, D., (2019), Milliyet Cocuk and the Making of Childrens Literary Culture in Turkey in the 1970s, International Research in Children's Literature (IRCL), 12(1), 62-75.

https://doi.org/10.3366/ircl.2019.0291

Original publication available at:

https://doi.org/10.3366/ircl.2019.0291

Copyright: Edinburgh University Press

http://www.euppublishing.com/ 


\section{Milliyet Çocuk and the Making of Children's Literary Culture in Turkey in the 1970s}

\section{Deniz Arzuk}

Deniz Arzuk is a visiting researcher and Raoul Wallenberg Institute fellow based at the Child Studies Unit at Linköping University. She received her PhD degree from The Ataturk Institute for Modern Turkish History at Bogazici University, with her thesis on the social construction of childhood in Turkey in the 1980s and the 1990s. Her research primarily deals with the relations between social change and the conceptualisations of childhood in the contemporary world, and she is particularly interested in children's rights, inequality, discrimination, and distinction.

\footnotetext{
$<$ Abstract $>$

This article is based on a systematic content analysis of Milliyet Çocuk, a children's magazine published by a left-leaning publishing house in the politically polarised context of Turkey in the late 1970s. It outlines the socio-political and cultural context, defines Milliyet Çocuk's position in the structure of the publishing field and questions how a non-majority group made space for themselves in a nation's children's literature.

The archival material used in this article has been collected for the course New Perspectives in Cultural History, taught by Prof. Cengiz Kirl1. My research is funded by the Swedish Institute.
}

<Key words:> Milliyet Çocuk, politicisation, ideology, Turkey, magazines, social realism

\section{$<\mathrm{A}>$ Introduction}

How is children's literary culture negotiated in a fragmented society? What are the structural factors that set the rules and frame this negotiation? How can non-majority groups take part in the making of literary culture? To address these questions, this article focuses on the example of Milliyet Çocuk, a children's magazine published by a left-leaning publishing house in the politically polarised context of Turkey in the late 1970s. According to Pierre Bourdieu, any study of trends, decision makings or the logic of literary publishing should 
take into account various constraints, such as the economic and symbolic limits of the decision makers, as well as their relation to numerous agents on both micro and macro levels. Additionally, the decisions taken by publishers should be contextualised within the global structure of the publishing field (124). However, when all things have been considered, Bourdieu concludes there is still some room left in which publishers can function as decision makers. Starting from this proposition, this article sets out the socio-political context in Turkey in the late 1970s, then situates Milliyet Çocuk in the structure of the field and, finally, discusses what the creators of the magazine achieved in that very limited space.

\section{$<A>$ Turkey in the 1970s}

In the last quarter of the twentieth century, Turkey was in the wake of a great economic depression, and economic growth was far from offering hope to the growing population that was increasingly concentrated in large urban centres. As the golden age of post-war welfare came to an end (Keyder 9), political tension began to escalate, and the society began to polarise on the right and the left ends of the political spectrum. This polarisation was reflected by both the political parties and the mass political organisations in the streets. In the parliament, the centre-left was represented by the social-democratic Cumhuriyet Halk Partisi [Republican people's party - CHP]. Although the party had shifted more to the left since the 1960s, Zürcher observes that its political position remained more moderate than the radical left mass movements that managed to mobilise the youth and the intellectuals (370). The extreme right, on the other hand, not only had a strong presence on the street, but was also represented in the parliament by the nationalist Milliyetçi Hareket Partisi [Nationalist movement party - MHP] and the Islamist Milli Selamet Partisi [National salvation party MSP]. 
Political division in the country was also reflected by the composition of parliament. The general elections of 1974 resulted in a hung parliament, which blocked CHP's efforts to form a government and resulted in a series of right-wing coalitions called the Milliyetçi Cephe [National front] governments. The coalitions were led by the centre-right Adalet Partisi [Justice party - AP], which was dependent on the support of both the MHP and the MSP. AP's dependency gave these smaller parties disproportionate influence (Ahmad 166). Thus, the government and the security forces began to take sides in the political conflict; polarisation turned into a deep division and led to armed violence.

Political polarisation had effects that extended beyond the political sphere and deeply resonated in the cultural debates at the time. It should be remembered that this was a period when cultural products were consumed en masse. For instance, in 1970 there were 2424 film theatres and around 250 million tickets were sold annually (Özön 389). Throughout the 1970s, the film industry had to share some of its influence with an emergent medium: television. Although there was a single channel, television became an important factor that shaped the cultural climate by the end of the decade (Toprak 378). Despite low adult literacy rates of roughly 65 per cent (Turkstat 18) and a relatively small number of publishing houses, the standard number of print runs for each new book was between 5000 and 10,000: five times more than the print runs today. Furthermore, there were almost 10,000 small bookshops dispersed all around the country, which also served as meeting points for locals (Doğan). Thus, gaining dominance in the cultural field was crucial for both camps, and political engagement became a prominent feature of the arts and culture scene in this decade.

\section{$<$ A $>$ An 'Ideological' Children's Literature}

In Imagined Communities, based on Hegel's famous statement on the function of newspapers, Anderson discusses the role of language in the formation of the nation state and suggests that 
reading newspapers was the mass ceremony that brought together modern communities (36). In the twentieth century, children's literature, and especially children's magazines as an important milieu of children's literary culture, served the same purpose for the child community in Turkey. It should also be kept in mind that curating children's culture was especially important for a young nation state like Turkey, which needed to break from its imperial past to build a new national identity: children were both the hope and the future of the new republic (Arzuk 'Nostalgia for Childhood'). Thus, children's literature was seen not only as a cultural product for the immediate present, but also as an investment in the future, and it became an important arena for competing ideologies.

It is no surprise then that several critical works on children's literature agree that the most important factor that determined the output of children's literature in Turkey in the 1970s was political polarisation. In these analyses, there appears to be a consensus that publishers' and authors' political engagement had a detrimental effect on the quality of children's literature. For instance, in an interview by Kanter, Şirin classifies the literature of this period as 'didactic and authoritarian' (398). Alpöge's criticism is even stronger, and she argues that the books produced in this period were not suitable for their audience: 'politicization hit children's books, and authors did not seem to care any longer about the specificities of their audience. Neither the language, nor the style, nor the subjects were appropriate for children' (28). Erdoğan also sees political polarisation as the most important factor that shaped children's literature, claiming that contrary to the first half of the decade, when high quality literary works were published, the second half of the 1970s was marked by 'clichés and stereotypes' ('Toplumsal tarihimizde' 88-9). In another article, he even calls these years a 'lost' period in terms of literary value:

Another turning point in children's literature was the period which started in 1975 and ended with the military coup in 1980 . The political left had reached its highest 
popularity by 1975 . Not only children's literature in general was influenced by this. This could easily be seen in the themes that authors chose as they wrote for children. Class struggle was the main theme, and the most common plot was that the regime of superior forces was destroyed by the ones who had been oppressed. Animal heroes who worked for superior animals revolted and set up new regimes of brotherhood and equality. It was not, therefore, surprising that the 1980 military coup prohibited the sale of some children's books. From the literary point of view, this period was a lost one, in the sense that politics controlled the production of new titles, which resulted in almost no books being published that had themes relating to children and their needs. ('Turkey' 1249)

Despite several important studies that observe the importance of children's periodicals in the late Ottoman and early republican periods (Kür, Okay, Kabacalı), there have been a limited number of studies that focus on magazines published after the post-war period. In the few examples that do mention children's magazines published in the 1970s, a similar question of what is and what is not appropriate for the child reader is central, echoing the critique of politicisation by children's literature critics. For instance, Ungan and Yiğit point out that Milliyet Çocuk was cherished by children, though they express some scepticism about magazines linked to newspapers and argue that their focus on current events is not age appropriate for child readers (193). Yalçın and Aytaş are also critical of children's magazines published by newspapers and state that they tend to impose their ideological views on children without paying attention to children's psychological development (88).

The common point of this criticism against politicisation is the apprehension of overt ideological messages in literary texts as corrupting literary value. In the case of children's literature criticism, this understanding is further supported by an emphasis on children's specific needs, such as the need for age appropriate topics and a consideration of their psychological and linguistic development. However, as John Stephens points out, 'there is no 
text without an ideology' (8). Bearing in mind McCallum and Stephens's assertion that 'a book which seems to a reader to be apparently ideology-free will be a book closely aligned to that reader's own unconscious assumptions' (360), what is criticised here is not ideological messages per se, but the radicalisation of the literature of this period compared to the critics' own ideological standing.

Some critique of indoctrination in children's literature was also voiced in the debates on children's literature in the 1970s. For instance, in his article on a recommended reading list for children's literature in Türk Dili, Tarık Dursun K. condemns several radical demands coming from leftist circles, such as their denunciation of folk tales, which were regarded as individualistic fantasies. He argues that instead of forcing a certain type of literature on children, they should be offered various alternatives that they can read critically. In other words, as a left-wing intellectual himself, what Tarık Dursun K. criticised was not ideological leaning in children's literature, but the way it was done without respecting children's autonomy as readers. Moreover, the fact that he chose to address leftist circles in an article about book recommendations for children reveals the extent of these circles' influence on children's literary culture at the time. Indeed, it would not be wrong to assert that it was their engagement and enthusiasm that fuelled a vivid debate on children's literature and sparked an interest in publishing for children.

The second half of the 1970s was an extremely productive period in Turkish children's literature. A number of left-wing authors began writing for children, led by prominent names like Yaşar Kemal, Orhan Kemal, Fakir Baykurt and Aziz Nesin. This opened the way for new authors, and as noted by Sheila Ray, this period saw more writers from rural and working-class backgrounds (782). The enrichment was not limited to the quantity of books published but was also evident in their themes. These works introduced 
social realism to children's literature by depicting children from working-class or urban poor families as protagonists.

The involvement of prominent authors attracted increasing interest in children's literature. For instance, two of the major arts and literature journals published special issues dedicated to the analysis of children's literary culture ('Çocuklar için' 228, 'Çocuk yazını' 39). These were also the years when large events were organised, such as roundtable discussions by official organisations (Demiray), and the very first children's literature book fair in Istanbul (Haber Merkezi). Productivity in publishing for children peaked in 1979, UNESCO International Year of the Child, when a previously unseen number of original and translated titles were published.

In her work on the radical and avant-garde children's literature of the interwar period in Britain, Kimberley Reynolds describes this period as a 'time of optimism, engagement, effort, and achievement' (216). Though perhaps neither as radical nor as avant-garde as in some countries, the literary works produced in Turkey in the 1970s were certainly as optimistic and engaged despite the social anxieties and escalating political violence. Unfortunately, this productive period in Turkish children's publishing came to an abrupt end with the military coup in 1980. The many children's books banned by the National Security Council after the coup included Mahi-ye siyah-e kuchulu [The little black fish] by Samad Behrangi, Meu Pé de Laranja Lima [My sweet orange tree] by José Mauro de Vasconcelos and Kuş ne yana öter [Whither sings the bird] by Iş11 Özgentürk to name a few. Most were examples of social realist children's literature. The level of censorship reveals how much importance was placed on what children read.

\section{$<$ A $>$ Milliyet, Abdi İpekçi and Ülkü Tamer}


Milliyet Çocuk began publication in this socio-political and cultural context. The magazine was published by the Milliyet group, founded by the Karacan family. The group owned a major literary publishing company in addition to the group's backbone Milliyet newspaper, which was among the bestselling national broadsheet newspapers at the time. The 1970s was a peculiar decade for journalism, when media ownership had not yet been taken over by large conglomerates and most newspapers were run by family holdings. Newspapers were still produced in traditional, modest offices in Babıâli, and offices had not relocated to massive media headquarters. A combination of several other factors, including strong labour unions and generous government subsidies, gave the journalists greater autonomy over their production.

Abdi İpekçi, who was both the editorial writer for the newspaper and the editor-inchief for Milliyet publications, was especially adept at using this welcome autonomy due to his strong personal relationship with the Karacan family (Karaca 140). İpekçi was an affluent journalist who sat on the boards of several professional associations, including the Türkiye Gazeteciler Sendikası [Journalists union of Turkey] and International Press Institute. Politically a moderate social democrat, İpekçi had given the newspaper its status as the voice of the left of centre since he assumed the position of editor-in-chief in 1955.

In the mid-1970s, one of the many novel ideas İpekçi had was to publish specialised newspaper supplements in magazine format every day of the week. Due to the interest in these supplements, some, including those accompanying the influential art magazine Milliyet Sanat, began to be sold as independent publications. Among them was Milliyet Çocuk, which was launched in 1974. Initially, Milliyet Çocuk was a bi-monthly magazine that printed several comics series such as Larry Yuma by Carlo Boscarato and Claudio Nizzi and Lucky Luke by Morris and René Goscinny. However, this first phase of the magazine did not last long; it ceased publication due to financial deficits when sales fell below 5,000. 
In 1977, İpekçi decided to give Milliyet Çocuk a second chance and approached Ülkü Tamer, who was at the time in charge of the children's section of Milliyet publications. Tamer gladly accepted the offer and brought together a modest staff of five people to relaunch Milliyet Çocuk as a weekly publication. Tamer had already been acknowledged as a translator, writer and poet long before he took over editing Milliyet's children's and arts sections. His poetry was considered to be a part of İkinci Yeni [the Second New poetic movement], an avant-garde school of poetry characterised by its surreal imagery and abstract language. Although İkinci Yeni was criticised for being detached from the social realities, its symbolist use of the urban landscape was strongly contextual and socially conscious, and the movement put its mark on poetry in Turkey for decades to follow.

As pointed out by Alpay, Tamer was among the three most important heads of children's sections of publishing firms in late 1970s Turkey. The other two were Tarı Dursun K., head of the children's section of Koza, and Erdal Öz, head of children's sections of Cem, Arkadaş and Can publishing houses (Alpay 11). All three editors were representatives of a new generation of intellectuals born in the 1930s. They were not part of the country's traditional elite but gained social mobility through their education in the schools of the new Republic after the rapid transition from the Ottoman Turkish version of the PersoArabic alphabet to Latin script with the Alphabet revolution of 1928, which was part of a larger cultural reform project. Although they were older than the rebellious youth of 1968 , they had their most productive years during an age of social uprising.

Tamer's interest in childhood preceeded his professional involvement in children's publishing. As pointed out by Özkara's study of Tamer, the child was a central and prominent figure in his poems, which he used as a symbol of innocence, purity and a desire to build a new world (166). His strong belief in the inherent positivity of childhood would later 
crystallise in his greatest gift to children, Milliyet Çocuk, which became an icon of children's culture under his editorship.

Apart from its significance in Turkish children's literary culture, Milliyet Çocuk should also be understood in the broader context of children's culture influenced by social changes making children's books less classist, racist and sexist in Britain in the 1960s and 1970s (Pearson, Making of 3). This was a widespread phenomenon across Europe, as revealed by research on how children's culture was revolutionised by the 1968 movements (Children's '68). The stories published in Milliyet Çocuk were reminiscent of the sociocritical and realist literature produced in Germany, which was almost always complemented by an optimistic outlook and hope for change (Grenz 141). The magazine's embrace of mass culture was akin to a parallel trait observed by Heywood in her work on the French publisher Hachette. This literary outlook was framed by an appreciation of the child as an agent, which echoed the politicisation of children's culture and empowerment of children in Scandinavia, as analysed in depth by Helle Jensen (97-108).

It should also be emphasised that similarities between Milliyet Çocuk and other examples of socially conscious children's literature were more intentional than coincidental. The literary circles in Turkey closely observed emergent international trends. The depth of their interest is illustrated by Ferhan Oğuzkan's overview of children's literature, which was not limited to national examples or the somewhat familiar Anglo-Saxon literature, but also focused on France, Germany, the Soviets and Scandinavian literatures.

\section{$<\mathrm{A}>$ Milliyet Çocuk}

The following findings are based on an analysis of the 75 issues of Milliyet Çocuk published after its second launch in January 1977. The research is limited to the period between that 
relaunch and İpekçi’s murder by ultranationalist gunman Mehmet Ali Ağca in February 1979. The assasination of İpekçi was a turning point for the magazine, not only because of the changes in the editorial board that followed, but also because the Milliyet group was taken over by a large publishing corporation after this date. In addition to a systematic content analysis of these issues and Tamer's memoirs, the research particularly focuses on three specific pages of the magazine: the editorial writings, the pen-pal advertisement columns and readers' pages, which published readers' own pieces of art and poetry.

\section{$<$ A $>$ The Readership}

Soon after its launch in 1977, partly due to the financial decline of Doğan Kardeş, which had previously been the most popular children's magazine, Milliyet Çocuk reached sales numbers as high as 100,000 . Who were these 100,000 children that read the magazine? Unfortunately, there are no publicly available records of Milliyet Çocuk's subscribers or sales patterns. The answer to that question offered in this study is based on an analysis of the 652 pen-pal notices published in the magazine during the research period, which contain valuable information about its readership.

Excluding gender neutral names, which were not very common in the 1970s, the number of notices from female readers is slightly less than that of males, the ratio being 44 per cent to 56 per cent. However it should be remembered that writing letters to an unknown pen-pal probably had different connotations for girls and boys, which might be one of the reasons behind the imbalance between the sexes. Although there are some letters from different age groups, the majority of the children that sent letters to the pen-pal column were between ten and fourteen years old. It can also be observed that Milliyet Çocuk had readers all around the country; its distribution was not limited to the city centres so it also reached many major districts. 
In similar notices published in children's magazines from the 1930s and 1940s, children often give some indication about their social status, such as their parents' professions, the type of school they attend or what they plan to be in the future. Contrary to those examples, Milliyet Çocuk's readers focus on their personal interests. Thus, distinguishing readers' social backgrounds proved to be complicated. However, a closer look at their interests reveals that Milliyet Çocuk attracted children from quite different backgrounds. While most children express their interest in affordable sports such as football and basketball, others are keen on those only available to a few such as skiing and riding horses. Moreover, while some children mention that they work, either to help their parents or as apprentices in workshops, several others imply that they spend their holidays in summer resorts. Apparently, the magzine appealed to children across the upper, middle and lower-middle classes.

Another factor that should be considered when assessing this audience profile is that it only reflects those children who sent notices to this one column for the specific purpose of finding pen-pals, and they probably were among those who owned copies of the magazine. The actual readership was much larger than that. Copies of the magazine were shared among groups of children and between siblings; many others read it in school and public libraries. Moreover, apart from readers who had access to the magazine at the time of publication, another hidden audience were the children who read it afterwards. In the 1970s, it was common practice to collect magazines and have them bound in hardcovers, which made them accessible to more than one generation of children.

\section{$<\mathrm{A}>$ Structure of the Field}

A more central question for the purposes of this analysis is how Milliyet Çocuk succeeded in reaching such a large audience. To understand this, the magazine needs to be situated in the structure of the field. First of all, Milliyet Çocuk was a commercial product, which is why it 
was closed down due to low sales numbers and relaunched when it seemed financially advantageous. Thus, one of the most important structural factors determining its position was market influence. Though unavailable today, the tracking of sales numbers was crucial for its existence and punctiliously monitored. Several marketing strategies were employed to increase circulation, including organising subscription campaigns or planning nationwide distribution according to seasonal travel patterns. Moreover, there was an apparent pressure, or at least the expectation, to stick with tried and tested templates for children's magazines. Tamer recalls how disappointed he was when he saw the proofs of the first issue put together in the classical magazine format, which he later discarded (276).

A second and equally pressing factor was competition. The success of Milliyet Çocuk led other magazines to follow in its footsteps, and several newspapers began publishing their own children's magazines. Most formidable of these was Tercüman Çocuk, which published in the exact same format as Milliyet Çocuk. However, Tercüman Çocuk was cheaper, and the comic series it published were very popular among certain groups of readers. Moreover, it was published by the nationalist Tercüman newspaper. Even though the moderate left-leaning Milliyet was not the exact political opposite of the extreme right-wing Tercüman, the difference and the rivalry between the two newspapers was quite apparent. Thus, competition was not only financial but also political.

Finally, the third factor that shaped Milliyet Çocuk was the creative team's agenda. The editorial staff, and especially Ülkü Tamer, had a very clearly defined notion about what they considered to be good for children. According to Tamer's memoirs, he accepted İpekçi's proposal to relaunch the magazine on the condition that he was given the autonomy and authority to recreate the magazine from scratch (275). He wanted to publish a high-quality literary magazine for curious, engaged and enlightened children. Thus began the editorial board's carefully choreographed dance with the publishers and the readers as they looked to 
find a balance between what they were expected to publish, what they wanted children to read and what their readers actually asked for.

\section{$<\mathrm{A}>$ Editorial Tactics and Strategies}

The first few issues of Milliyet Çocuk reveal the kind of magazine Ülkü Tamer envisioned. The new Milliyet Çocuk was published in the format of a literary journal. It was 52 to 68 pages long, and it had an editorial piece, several columns and small fonts for a children's paper. It published stories by famous writers and articles on a variety of subjects from mythology to science and popular culture. While he had a vision for the magazine, Tamer was also curious to find out children's opinions about it. That is why, starting from the first issue, the new Milliyet Çocuk tried to initiate a dialogue with the readers: 'Dear readers, do let us know what you think about our magazine. What you liked, what you did not. Tell us what you want. This is your magazine. You lead the way' (Milliyet Çocuk 1). The form of address of 'dear readers' and not 'dear reader' can be read as a sign of seeing children as a separate community. The editorial board did not address a single child that was reading the magazine on her own; rather, they addressed children as a community.

It is interesting to note that this attitude, although apparently cherished by the children, was frowned upon by the scholarly critics at the time of publication, who interpreted it as a form of self-promotion (Baraz 374). Yet, this dialogue was not simply tactical; it was also a reflection of a deeper socio-political change. According to Necmi Erdoğan, what differentiated the left-wing populism of the 1970s from the earlier progressive movements was the way it related to the masses. He argues that they abandoned the Kemalist motto 'for the people, despite the people', symbolic of social engineering, and adopted a much more egalitarian approach that Erdoğan summarises as 'for the people, with the people' (28). 
The editorial staff used several other methods to elicit the responses of children. For instance, the magazine published various questionnaries asking readers about their ages, genders, weekly allowances and even the newspapers their parents read. There were many other surveys that asked their ideas on the guest celebrities to be invited to contribute to the magazine, which TV shows they liked and why they liked those particular shows. The Milliyet Çocuk report cards were perhaps the most creative and playful of these surveys. Report cards were published anually, and the children were asked to grade the contents of the magazine.

What is more surprising is the extent to which children responded to these campaigns. And the editorial team evidently listened. Unfortunately, the results of these opinion surveys, campaigns and questionnaires are neither available through the pages of Milliyet Çocuk nor kept in the archives. However, it is possible to form conjectures about their role in the development of the magazine by analysing the changes in the content of the magazine. Evidence suggests that children's answers were carefully read and several changes were made according to their opinions. In other words, their positioning as consumers gave the children the power actually to shape the magazine they read.

One significant change was the introduction of popular culture into the pages of Milliyet Çocuk. As mentioned before, the magazine had quite a diverse audience, yet one of the things that brought these children from different parts and strata of the country together was popular culture. The orientation of children to popular culture was not a phenomenon peculiar to Milliyet Çocuk's readership. In the 1970s, as the boundaries between the cultural universes of the children and adults began to blur, the interest in popular spectator sports, music, cinema and television were shared by children and adults alike.

The change in Milliyet Çocuk is very apparent: as the educative pages diminished, subjects like news about celebrities, television shows, football and popular music began to 
occupy an increasing proportion of the magazine. By 1978, many of these subjects were allocated special sections. The television, cinema and music pages published focused articles about television shows, movies and records. The magazine interviewed a celebrity each week, who was chosen by the readers, and even started giving out coloured posters with every issue.

Not all reader response was as welcomed by the editors. Tamer recalls his disappointment at the results of the first ever Milliyet Çocuk report card, which revealed that the readers' favourite section was Larry Yuma, the comic series, while the least popular was Tamer's favourite section, the short stories (Tamer 282). This exposed the greatest clash between the editorial board's ideas and the readers' wishes about the inclusion of comics. Following in the footsteps of Vedat Nedim Tör, the legendary editor of Doğan Kardeş, Tamer tolerated comics only because they could be used as stepping stones to developing the habit of reading more 'proper' literary works (Cantek).

Yet the children strongly disagreed with Tamer, and their wishes were acknowledged. According to readers' feedback, the 50:50 ratio between comics and writing in the first issue rapidly changed in favour of comics. By the end of the first year, the comics to writing ratio moved to $64: 36$, and in the second year of publication, comics comprised over 70 per cent of the magazine. However, while the editorial board respected children's preferences, they also tried various strategies to bring these closer to their own values. For instance, they invited well-known illustrators such as Mistık to create original comic series and published comics based on classical novels by western authors, such as Charles Dickens, Jules Verne and Jack London.

The section that was closest to Ülkü Tamer's heart were the stories written by famous authors such as Aziz Nesin, Bekir Yıldız, Selim İleri, Mehmet Seyda, Adnan Özyalçıner, Süreyya Berfe, Ömer Faruk Toprak, Oktay Akbal, Yaşar Kemal and many others who were known for their clearly defined ideological stances. What these stories had in common was 
their social realist outlook and themes such as poverty and social injustice. In his memoirs, Tamer narrates how he defied concerns over the prospects of the magazine with his belief that children could change. He sincerely believed that children were capable of changing, and they did change. By the end of 1978, the results of the new report cards revealed that the stories had become the readers' favourite (282). Although Tamer's memoirs should not be read as an unbiased account of what happened, it should nonetheless be acknowledged that many of the established names who contributed to Milliyet Çocuk's short stories section have never gone out of print and are still considered canonical authors of children's literature.

Moreover, reflections of the world-view presented in these stories found its way into the children's own languages. Starting from its first issue, Milliyet Çocuk had a special page reserved for the readers' own creations, where children's drawings, stories and poems were featured. The majority of children's poems published in these pages were probably written as school assignments, and most of them began and ended in a similar style. Yet there were also very personal poems about children's daily lives, and these poems directly or indirectly, consciously or unconsciously reflected the values Milliyet Çocuk hoped to introduce to its readership. There were many poems in which motifs borrowed from the social realist discourse surfaced rather surprisingly, often standing out out by their irrelevance to the general context of the poem (Arzuk 'Nostalgia for'). These provide the strongest evidence of how deeply the readers engaged with the magazine and reproduced its literary culture and political values, as exemplified by this short but multilayered little poem:

Made with so much labour and so much sweat

You have served many a purpose

Yet you will be left and forgotten once you are worn out My bag, my darling bag (Yazıc1) 


\section{$<\mathbf{A}>$ Conclusion}

Flemming Mouritsen identifies three main types of child culture: culture for children, culture with children and children's culture (16). Milliyet Çocuk managed to be part of all three types: first it was a cultural product produced by adults for children, but then it was recreated through an interactive relationship between readers and editors. Finally, it became a part of children's own culture that they recreated through interpretation and shared with their peers. Milliyet Çocuk owed this multilayered status to a continued relationship with its audience. Rather than submitting to ideological and financial pressures, the editorial board managed to utilise these constraints to their advantage. Thus, they managed not only to manoeuvre within the small space left by their structural position, but also to conquer the challenges presented by this position by turning it into an opportunity to initiate a dialogue with the child reader.

In her work on Leia Berg's Nippers series of child-centred early reader books, Pearson observes that the series owed its success to a 'convergence between counter-cultural ideals and the mainstream' ('The right to read' 21). Similarly, Ülkü Tamer's Milliyet Çocuk succeeded in bringing the marginal into the mainstream. In doing so, the magazine's editorial team neither obediently submitted to the readers' real or perceived demands, nor stubbornly insisted upon publishing what they deemed was proper children's literature. Instead, they regarded their audience as their equals. That was how they managed to be graciously flexible and make the changes children asked for, yet remained respectfully determined to publish what they wanted at the same time.

\section{$<$ Works Cited $>$}

Ahmad, Feroz. The Making of Modern Turkey. London; New York: Routledge, 1993.

Alpay, Meral. 'A Survey of Turkish Children's and Juvenile Literature'. Bookbird 18 (1980): $10-11$. 
Alpöge, Gülçin. 'New Trends in Children's Literature in Turkey Today'. Bookbird 40.1 (2002): 27-30.

Anderson, Benedict. Imagined Communities: Reflections on the Origin and Spread of Nationalism [1983]. London: Verso, 2006.

Arzuk, Deniz. 'Creating a Nation from Scratch: Nationalism and Nationhood in Çocuk Children's Periodical in Turkey, 1936-39'. Children's Literature on the Move: Nations, Translations, Migrations. Eds Nora Maguire and Beth Rodgers. Dublin: Four Courts Press, 2013.

---. 'Nostalgia for Childhood: Children's Experiences of Political Conflict in Turkey in the late 1970s'. Paper presented at Growing up in Divided Societies International Conference, Queen's University Belfast, June 2010.

Baraz, Turhan. 'Çocuk dergilerinde ileti çözümlemesi' [Communication analysis of children's magazines]. Kurgu 4 (1981): 365-81.

Bourdieu, Pierre. 'A Conservative Revolution in Publishing'. Translation Studies 1.2 (2008): $123-53$.

Cantek, Levent. ‘Ülkü Tamer, Larry Yuma’ya karşı’ [Ülkü Tamer vs. Larry Yuma]. 2006. (Date accessed: 26.02.2019) <http://derinhakikatler.blogspot.com/2016/10/ulkutamer-larry-yumaya-kars.html>

Children's '68. 'About the children's ‘68'. 2018. (Date accessed: 26.02.2019) $<$ https://children68.hypotheses.org/about $>$

‘Çocuk yazını'. Türk Dili ve Edebiyat Dergisi 39 (1979): 331.

‘Çocuklar için ...'. Milliyet Sanat 228 (1977).

Demiray, Kemal. ‘Açık oturum: çocuk yazını' [Panel: children's literature]. Türk Dili Dil ve Edebiyat Dergisi 39.331 (1979): 89-93. 
Doğan, Ali Necati. 'Türkiye'de yayıncılık: Cumhuriyet dönemi kitap yayıncılı̆̆ı' [Publishing in Turkey: book publishing in the Republican period]. Milliyet Blog, 13 August 2009. (Date accessed: 26.02.2019) < http://blog.Milliyet.com.tr/turkiye-de-yayincilik--cumhuriyet-donemi-kitap-yayinciligi/Blog/?BlogNo=197045>

Erdoğan, Fatih. 'Toplumsal tarihimizde çocuk edebiyatının yeri’ [The situation of children's literature in our social history]. Toplumsal tarihte çocuk [The child in social history]. Istanbul: Tarih Vakfi Yurt Yayınları, 1993. 85-91.

---. 'Turkey'. International Companion Encyclopaedia of Children's Literature (2nd edition). Ed. Peter Hunt. London; New York: Routledge, 2004. 1246-51.

Erdoğan, Necmi. 'Demokratik soldan Devrimci Yol'a: 1970'lerde sol popülizm üzerine notlar' [From the democratic left to the Revolutionary Path: notes on left populism in the 1970s]. Toplum ve Bilim 78 (1998): 22-37.

Grenz, Dagmar. 'Realistic Stories for Children in the Federal Republic of Germany, 19701994: Features and Tendencies'. Reflections of Change: Children's Literature since 1945. Ed. Sandra L. Beckett. California: Greenwood Pub Group, 1997.

Haber Merkezi. 'İstanbul Uluslararası Çocuk Kitapları Fuarı açıldı’. Milliyet 27 March 1979. Heywood, Sophie. 'Modernising and Moralising: Hachette's Mass-Market Fiction Series for Children, 1950s-1960s'. Strence 11 (2016). (Date accessed: 26.02.2019) $<\mathrm{http}$ //journals.openedition.org/strenae/1640>

Jensen, Helle Strandgaard. From Superman to Social Realism: Children's Media and Scandinavian Childhood. Amsterdam; Philadelphia: John Benjamins, 2017. K., Tarık Dursun. 'Çocuklara kitaplık' [A library for children]. Türk Dili Dil ve Edebiyat Dergisi 39.331 (1979): 298-302. 
Kabacalı, Alpay. 'Çocuk Edebiyatı'. Cumhuriyet dönemi Türkiye ansiklopedisi cilt 3 [The encyclopaedia of Republican Turkey, volume 3]. Istanbul: İletişim, 1983. 607-10.

Kanter, Beyhan. 'Mustafa Ruhi Şirin ile dünden bugüne çocuk edebiyatımız, clasik ve kanonik kitaplar üzerine söyleşi’ [An interview with Mustafa Ruhi Şirin on children's literature from the past to the present, and on classical and canonical books]. Türk Dili Dil ve Edebiyat Dergisi 42.756 (2014): 393-404.

Karaca, Emin. Milliyet olayı [The Milliyet incident]. İstanbul: Altın, 1995.

Keyder, Çağlar. Ulusal kalkınmacılı̆̆ın sonu [The collapse of national developmentalism]. İstanbul: Metis, 1993.

Kür, İsmet. Türkiye'de süreli çocuk yayınları [Children's periodicals in Turkey]. Ankara: Atatürk Kültür Merkezi, 1991.

Kür, İsmet. Türkiye'de süreli çocuk yayınları [Children's periodicals in Turkey]. Ankara: Atatürk Kültür, Dil ve Tarih Yüksek Kurumu, 1991.

McCallum, Robyn and John Stephens. 'Ideology and Children's Books'. Handbook of Research on Children's and Young Adult Literature. Eds Shelby A. Wolf, Karen Coats, Patricia Enciso and Christine A. Jenkins. Abingdon: Routledge, 2010. 359-71.

Mouritsen, Flemming. 'Child Culture - Play Culture'. Childhood and Children's Culture. Eds Flemming Mouritsen and Jens Qvortrup. Odense: University Press of Southern Denmark, 2002. 14-42.

Oğuzkan, Ferhan. 'Dünyada ve bizde çocuk yazınının gelişmesine toplu bir bakış’ [An overview of the development of children's literature here and in the world]. Türk Dili Dil ve Edebiyat Dergisi 39.331 (1979): 261-83. 
Okay, Cüneyd. Eski harfli çocuk dergileri: inceleme [Children's magazines in old script: a survey]. Istanbul: Kitabevi, 1999.

Özkara, Okan. 'Ülkü Tamer'in şiirlerinde yeni bir dünyanın oluşumundaki rolüyle çocuk' [The image of the child as the maker of a new world in Ülkü Tamer's poems]. Karadeniz 36 (2017): 164-75.

Özön, Nijat. Sinema [Cinema]. İstanbul: Hil, 1985.

Pearson, Lucy. The Making of Modern Children's Literature in Britain: Publishing and Criticism in the 1960s and 1970s. London; New York: Routledge, 2016.

---. 'The Right to Read: Children's Rights and Children's Publishing in Britain'. Strence 13 (2018). (Date accessed: 26.02.2019) $<$ http://journals.openedition.org/strenae/1861>

Ray, Sheila. 'Turkey'. International Companion Encyclopaedia of Children's Literature (1st edition). Ed. Peter Hunt. London; New York: Routledge, 1996. 781-2.

Reynolds, Kimberly. The Forgotten History of Avant-Garde Publishing for Children in Early Twentieth-Century Britain. Oxford: Oxford University Press, 2016.

Stephens, John. Language and Ideology in Children's Fiction. London; New York: Longman Limited, 1992.

Tamer, Ülkü. Yaşamak Hatırlamaktır [To live is to remember] [1998]. Istanbul: Yapı Kredi, 2017.

Toprak, Bedirhan (ed.). Cumhuriyet ansiklopedisi (1923-2000), Cilt 3: 1960-1980 [Encyclopaedia of the Republic (1923-2000), volume 3: 1960-1980] [1998]. Istanbul: Yap1 Kredi, 2002.

Turkstat. Statistical Indicators 1923-2009. Ankara: Turkstat, 2010. 
Ungan, Suat and Yiğit, Fadime. 'Geçmişten günümüze Türkiye'de süreli çocuk yayınları' [Periodical publications for children in Turkey from the past to the present]. Dil ve Edebiyat Eğitimi Dergisi 10 (2014): 184-98.

Yalçın, Alemdar and Aytaş, Gıyasettin. Çocuk edebiyatı [Children's literature]. Ankara: Akçăg, 2005.

Yalçın, Murat (ed.). 'Ülkü Tamer'. Tanzimat'tan bugüne edebiyatçılar ansiklopedisi [Encyclopaedia of authors from Tanzimat to the present]. Istanbul: Yap1 Kredi Yayınları, 2003. 936-7.

Yazıc1, Mete. 'Çantam'. Milliyet Çocuk 23 June 1978.

Zürcher, Erik Jan. Turkey: A Modern History [1993]. London; New York: IB Tauris, 2004. 